\title{
A EXISTÊNCIA NEGRA NA FILOSOFIA DA CULTURA ${ }^{1}$
}

\author{
Lewis Gordon ${ }^{2}$ \\ Tradução por Cleber Daniel Lambert da Silva ${ }^{3}$ \\ Universidade da Integração Internacional da Lusofonia Afro-Brasileira \\ (UNILAB) \\ https://orcid.org/0000-0001-8846-8107
}

Este $\operatorname{artigo}^{4}$ explora algumas das relações entretidas entre a filosofia da cultura e a existência negra e, por extensão, entre esta última e a filosofia Africana ${ }^{5}$. Uma parte ampla dessa discussão será meta-filosófica - ela incidirá sobre a filosofia - , mas sua própria significação filosófica deverá aparecer ao longo do percurso.

A existência negra evidência uma tensão central no pensamento moderno. Ao mesmo tempo em que celebra o valor da liberdade, o pensamento moderno foi, em grande parte, também, uma racionalização da escravidão e ignorou as ideias dos Negros acerca da escravidão e da liberdade, o que leva a questionar em que medida o pensamento filosófico está comprometido com a verdade e a realidade. A razão alegada para excluir o pensamento negro é um pretenso compromisso com temas autenticamente universais. Pode-se mostrar facilmente que isso assume freqüentemente a forma de uma presunção da particularidade da negritude alargada pela força universalizante da branquitude. Que o lugar da branquitude ignore a negritude, ao passo que o lugar da negritude defina-se em relação à branquitude (e a outros prestadores de pensamento simbólico)

\footnotetext{
${ }^{1}$ A presente tradução para o português foi elaborada a partir da tradução para o francês, por Cristhine Klein-Lataud, do artigo "Black Existence in Philosophy of Culture", publicado originalmente pela revista Diogenes, 2014, Vol. 59 (3-4), 96-105. Ela foi revisada integralmente a partir do original em inglês pela Professora Doutora Thais Joi Martins (Universidade Federal do Recôncavo da Bahia). Nossos mais sinceros agradecimentos ao Professor Lewis Gordon pela gentil permissão para realizar a tradução para o português [N. do T.].

${ }^{2}$ Professor Doutor na University of Connecticut, USA. E-mail: lewisgordon@uconn.edu

${ }^{3}$ Doutor em filosofia e professor da Universidade da Integração Internacional da Lusofonia Afro-Brasileira (UNILAB), Bahia - Brasil. E-mail: cleberlambert@unilab.edu.br

${ }^{4}$ Esse artigo é uma versão revisada da Conferência Sprague/Springer apresentada pelo autor ao Colégio Brooklyn, em maio de 2010. Uma primeira versão foi igualmente apresentada ao Colégio Spelman. Gostaria de agradecer Matthew Moore, Emily Michael, Nanette Funk, SaamTrivedi, DenaShottenkirk e todos os meus colegas do Brooklyn College que me acolheram na qualidade de Jay Newman Invited Professor em Filosofia da Cultura, durante o semestre da primavera de 2010. Sou igualmente grato à Gertrude Gonzalez de Allen, Al-Yasha Williams, Nami Kim e Rosetta Ross por sua generosidade e sua partilha intelectual quando de minha visita a Spelman.

${ }^{5}$ Traduziremos "Africana philosophy" por filosofia Africana. (N.T.).
} 
conduz a uma completa mudança de perspectiva: a branquitude só é universal na medida em que ignora a realidade. É um particular que afirma o universal. Ora, o fato de que a negritude admita sua relatividade significa que ela é não $o$ universal, mas ao menos um conceito mais universalizante. Encontramos essa observação em todo pensamento Diaspórico-Africano (cf. Henry, 2000; Gordon, 2008a). Uma tal tomada de consciência começa também a aparecer em certas abordagens de pensamento político e filosófico que, de início, não reconheciam o pensamento DiaspóricoAfricano, por exemplo os trabalhos de Sibylle Fischer (2004) e de Susan Buck-Morss (2009).

O contraste entre particularidade negra e universalidade branca suscita dificuldades suplementares quando são abordados temas negros. Uma delas consiste no fato de que esses temas são abordados de maneira neurótica: assim, a verdade é desqualificada em função do orador ou do sujeito, o sofisma clássico do argumento ad hominem aplicado ao eu. Encontramos um exemplo nas discussões recentes acerca da África, onde é exigido, especialmente no "atlantismo negro", que o discurso seja "sem raça": mas quando o debate é ampliado para nele incluir Santo Agostinho da alta Idade Média, IbnRushd e Maimônides do período Medieval tardio, alguns se opõem a tal inclusão. Não vejo outra base sobre a qual assentar tal objeção a não ser a suposição de que esses autores não sejam negros. $\mathrm{O}$ fato de que Santo Agostinho seja originário daquilo que é hoje a Argélia, e de que Ibn Rushd e Maimônides sejam do norte da África, aquele primeiro um Mouro, este último um Judeu, funda suas conexões africanas. A objeção segundo a qual os Norte-Africanos não são Africanos resulta da má fé ${ }^{6}$.

A má fé em questão é agravada por um problema de Teodiceia quanto ao modo como a negritude é estudada nos textos filosóficos, em que a expectativa de infelicidade é continuamente presente enquanto fenômeno extra-textual. Como todos os diplomados negros em filosofia puderam notar, em um momento ou outro, os filósofos europeus modernos não mostram afeição pelos Negros. As páginas consagradas a sua humilhação, quer seja nos escritos de Hume, de Kant ou mesmo do tão progressista Mill, levantam a questão do preconceito ocultado por trás dessas vozes da razão. Quando eu indicava essas passagens a colegas durante meus estudos de doutorado, a reação deles consistia sistematicamente: 1) em negar a existência de tais passagens; 2) em refletir com descrença no por que não as tinham visto até então; 3) em provar de pronto que elas não eram pertinentes. Entretanto, acontece que, na nossa profissão, o conhecimento depende daquilo que pode parecer o ponto mais trivial ou mais periférico, como o demonstram os trabalhos exegéticos e filológicos sobre as filosofias gregas e romanas ou sobre a hermenêutica do idealismo alemão. Esse recurso precipitado ao argumento segundo o qual as passagens racistas não

\footnotetext{
${ }^{6}$ Para uma discussão crítica mais aprofundada ver Chrisman (2002) e Gordon (2008a).
} 
têm relevância suscitam, pois, uma certa desconfiança. A teodiceia, como se sabe, mostra como a onisciência e a onipotência de Deus coincidem com sua justiça e sua bondade. Se a injustiça e o mal existem, como, então, uma tal divindade poderia ser responsável por isso? As respostas clássicas, desde a época de Santo Agostinho, são duplas: as intenções da divindade ultrapassagem a compreensão humana, ou então a divindade, como no judaísmo, no cristianismo ou no islamismo, dotou a humanidade com o livre arbítrio, o que, por consequência, explica que muitos seres humanos façam uso de sua liberdade para perpetrar o mal. Nessas duas racionalizações, a divindade permanece intacta e a culpa, seja por interpretar os acontecimentos como sendo maus e injustos, seja por tê-los criado, é cometida pelos seres humanos. Poderíamos chamar a isso de gramática da teodiceia. Nas práticas de teodiceia, apresenta-se algo como intrinsecamente bom, o que converte a injustiça e o mal em elementos exteriores. Tais abordagens operam igualmente em práticas textuais, em que se trata um autor ou um texto como uma divindade, sendo todos os elementos negativos rejeitados para o exterior. Chamemos isso de teodiceia do texto. Meus colegas eram prisioneiros de uma leitura teodiceana do padrão filosófico moderno. Esse viés subjacente afeta sua própria prática de leitura, tornando invisíveis essas passagens. Seria o caso de perguntar: o que é que, em sua relação com esses textos e, na verdade, com a tradição que eles sustentam, promovia sua cegueira? Aquilo que estava em jogo encontrava-se ligado a uma dupla consciência, sobre a qual eu retornarei em breve. Por enquanto, consideremos o seguinte. Numerosos estudantes negros já vivem as contradições do sistema. Assim, a ideia de estudar os clássicos europeus sem encontrar aí elementos racistas é uma ilusão ingênua. Hume, Kant, Hegel e Nietzsche e muitos outros pensadores europeus eram seres humanos que carregavam neles e encarnavam os costumes de sua sociedade. Alguns se encontravam em melhor situação em relação a outros acerca disso, mas todos, no final das contas, eram seres humanos. Os leitores que esquecem isso estão em busca de deus. E, às vezes, nossos esforços para tornar suas pessoas e seus pensamentos conforme ao que é justo e bom nada mais são do que uma queda em uma teodiceia laica.

\section{Problemas de cultura}

Problemas de cultura emergem do mundo da negritude como consequência de um deslocamento na filosofia primeira. Enquanto a ontologia ou a epistemologia dominam, provavelmente, a filosofia ocidental, a reflexão filosófica dos Negros concentra-se sobre a antropologia filosófica, ela mesma focalizada sobre a liberdade e a relação dos homens com a razão. É a partir dessa constatação que em meus trabalhos (GORDON, 2008a) depreendi três eixos principais da filosofia Africana: 1) a antropologia filosófica; 2) a filosofia da liberdade; 3) a meta-crítica da 
razão. Negro e Africana não são sinônimos, porque as coisas negras não são necessariamente Africanas ou nascidas da Diáspora Africana e porque as coisas da Diáspora Africana não são necessariamente Negras. Salvo se apelarmos para migrações humanas muito antigas, a identidade negra dos Aborígenes Australianos não se refere a uma identidade Africana. Da mesma maneira, as antigas populações não-negras da África nada mais são do que Africanas agora, sem ser necessariamente negras. Entretanto, ser Africano colocou desafios no mundo moderno e o mesmo pode ser dito acerca do fato de ser negro: os desafios aos quais são confrontadas a filosofia negra e a filosofia Africana são, no fundo, similares. Portanto,prosseguirei, com a discussão acerca delas como se fossem praticamente intercambiáveis, ainda que os leitores não devam esquecer sua diferença.

Os três motivos que apresentei acima nos conduzem a três questões correlatas: a) O que significa ser humano? Em outras palavras, quais são os critérios que nos permitem compreender nossa humanidade?; b) $\mathrm{O}$ que significa ser livre e liberto?; c) Como justificar o raciocínio que fundamenta as duas primeiras questões? A questão de antropologia filosófica emerge da realidade histórica: a contestação da humanidade do povo negro. Para aqueles que foram escravizados, ser designados como "propriedade" levantava questões acerca do significado de ser humano quando não se tem a posse de si mesmo - na verdade, quando não se tem o direito de possuir qualquer coisa. $\mathrm{O}$ impacto do racismo foi tal que grupos inteiros de seres humanos foram declarados como não satisfazendo aos critérios que definiam a espécie humana. Muitos daqueles cuja humanidade foi contestada reagiram inicialmente proclamando sua igualdade com aqueles que a contestavam. Porém, o equívoco de tal abordagem consiste em reconhecer a legitimidade do contestador como norma. Com efeito, o grupo contestado aceitava o direito do contestador como norma do valor humano. Contudo, como isso seria possível, se a norma do contestador é de nível tão baixo? Além disso, como o excluído conhece quais as normas apropriadas para atestar a humanidade em primeiro lugar? Essas reflexões recaem sobre as normas à luz das quais a humanidade deveria ser medida - ainda que essa medida seja freqüentemente falsa (GOULD, 1981; GORDON, 1995; TAYLOR, 2004). Determinar tais normas representa uma das problemáticas essenciais da antropologia filosófica (GORDON, 2008a).

Dedicar a reflexão filosófica a uma teoria da liberdade parece lógico para um povo que sofreu com a colonização e o racismo. A liberdade é um tema central do pensamento moderno europeu moderno e os negros enquanto negros possuem uma ligação simbiótica com o mundo moderno: esses dois fatos destacam o aspecto particularmente moderno do pensamento filosófico negro. Ainda que, antes da era moderna, se tenha refletido no mundo inteiro acerca da escravização, a concepção de liberdade enquanto meta da vida humana e sua relação indissolúvel com o ser humano 
estão a tal ponto fixadas no mundo moderno que a filosofia Negra e a filosofia Africana encontram-se na vanguarda da teorização das contradições da vida moderna. Retornarei a esse ponto mais adiante.

A meta-crítica da razão explora o modo como a razão se comporta em face dessas duas problemáticas. As explicações que apresentei até aqui ilustram essas justificações. Como justificamos as afirmações da antropologia filosófica, sua concepção da liberdade e suas relações mútuas? De maneira mais radical, como justificar o uso da razão aqui? Lançar mão da razão é justificado em um contexto onde ela é freqüentemente utilizada para justificar práticas desumanizadoras? Essas questões meta-críticas sobre a razão desembocam em inúmeras outras, das quais muitas são metafilosóficas. Por exemplo, nossas concepções da racionalidade funcionam de maneira colonizadora (MIGNOLO, 1999; MALDONADO-TORRES, 2007)? Frantz Fanon refletiu bastante acerca dessa questão. Em Pele negra, máscaras brancas, ele defende que "há um ponto em que os métodos se dissolvem" (FANON, 1971, p. 11). Ele quer dizer com isso que a fetichização do método desvia-nos da realidade. Além disso, se a gramática de nosso método é colonial, poderíamos produzir relações coloniais até na maneira com a qual pretendemos combatê-las. Para Fanon, isso levava a suspeitar até mesmo do método. Chega-se, assim, ao paradoxo que consiste em submeter o método à crítica através de um método sem método, um método que consiste em não ter método. Fanon colocou um problema similar em relação à razão, o sine qua non da filosofia.No mundo moderno, o Negro enfrenta uma relação neurótica com a razão. Para retomar a expressão de Fanon, quando ele estava lá, a razão não estava; quando ela estava, ele não estava mais.Fanon queria dizer que a razão encontrava um meio de escapar quando ele entrava em um lugar enquanto homem negro, ou pior, enquanto preto, a palavra francesa para negro e nigger. A razão ou, para continuar com a nossa singularização dos falsos universais, a razão ocidental, encontrava um meio de se tornar irracional quando os Negros entravam em cena. Para tornar as coisas ainda mais graves, irracionalidade foi considerada razoável. Como Fanon combateu isso? Se ele tentasse forçar a razão a ser razoável, ele seria a manifestação da irracionalidade. Ele enfrentou a tarefa de abordar razoavelmente a irracionalidade. A ironia da situação de Fanon e, por extensão, da filosofia dos Negros é que eles defendem aquilo que atentou contra a sua humanidade. A relação dos Negros com a filosofia é, portanto, profundamente ambivalente, sempre carregada pela perda no momento do ganho. Em termos psicanalíticos, tratase de melancolia (FREUD, 1949). A existência negra se torna uma espécie de "embaraço" com a reação teodiceana que coloca os Negros em uma relação exterior com a tradição filosófica ocidental. Como vimos em nossa discussão acerca da teodiceia, as forças dominantes se sentem obrigadas a se defender. A exclusão da realidade negra em relação ao mundo do pensamento e das altas esferas deve se justificar se o sistema, afinal de 
contas, for justo. Tal defesa provoca freqüentemente apelos ao maniqueísmo, sendo necessário afirmar que a desumanização dos Negros é uma ação legítima em um mundo governado por uma lógica bipolar em que negro e branco são diametralmente opostos. Sua significação foi muito bem depreendida por W.E.B. Du Bois há mais de um século, através de sua fórmula: Howdoes it feeltobe a problem? [como é o sentimento de ser um problema?] (Du Bois, 1993). Pode-se transpor essa experiência existencial sentir sua relação com o mundo como sendo problemática, encontrar-se um pouco em desequilíbrio - em What does it mean to be a problem? [O que significa ser um problema?] (Gordon, 2000). O encontro da hermenêutica/interpretação com a ontologia (do sentido e do ser) vem à tona nesse momento. Esse deslocamento, esse sentimento de não estar em seu lugar e a questão de seu sentido colocam um problema de justificação. Se a gente é um problema, então por que a gente está aqui?

Esse problema (de ser um problema) levanta igualmente questões epistemológicas e metodológicas. Du Bois observou, por exemplo, que o fato de tratar os Negros como problema e não como pessoas confrontadas com problemas conduz a um problema teodiceano e a um problema de epistemologia social. O primeiro implica uma coerência sistemática que exige a eliminação ou a rejeição para o exterior de tais seres. Em outros termos, eles são estrangeiros. É um paradoxo, já que seu estatuto de estrangeiro decorre desse sistema. Isso faz deles seres governados interiormente por um sistema que recusa toda responsabilidade pelas condições que os tornam incompatíveis com ele. O segundo é também um problema teodiceano, mas no nível da integridade epistemológica e teórica. Nele, a ordem epistemológica e teórica é completa, o que faz com que esses indivíduos problemáticos devam "entrar" no sistema. Resulta disso um esforço para colocar à força as pessoas no quadro epistêmico, na teoria, com todas as conotações que a expressão colocar à força implica. Ela supõe, por definição, a inadaptação.

\section{Decadência e dupla consciência}

Eu dei o nome de decadência disciplinar (GORDON, 2006) ao esforço fornecido para dar completude aos modelos teóricos nas ciências humanas, de modo que as hipóteses sejam aplicadas ao conjunto do real. Esse esforço atribui um alcance ontológico a suas hipóteses metodológicas. Recordemos que Fanon identificou esse problema quando ele argumentou que, para tratar os problemas de colonialismo e de racismo, deve-se transcender as hipóteses metodológicas: se as práticas coloniais existem também no plano epistemológico, essas próprias hipóteses podem ser contaminadas. A colonização epistemológica é também metodológica. A investigação paradoxal, levada adiante por Fanon, acerca de um método sem pressupostos pode ser reformulada através daquilo que eu chamo de 
suspensão teleológica do método. Esta, por sua vez, está ligada a uma suspensão teleológica da disciplinaridade (GORDON, 2006; KIERKEGAARD, 2000). Uma suspensão teleológica da filosofia é um paradoxo análogo. Ela implica que a filosofia vá para além da filosofia, de modo a engendrar uma nova filosofia e, talvez, outras possibilidades disciplinares para além da filosofia. Curiosamente, essas suspensões teleológicas da filosofia designam aquilo que ao menos os "grandes" filósofos sempre praticaram. Santo Agostinho foi o teólogo que desejou ir para além da filosofia, em razão de sua fé, desenvolvendo, dessa maneira, ideias fundamentais para a filosofia medieval. Descartes foi o matemático que desejou ir para além das concepções escolásticas da filosofia em nome da investigação científica. O resultado foi a asserção da epistemologia como filosofia primeira e um esforço radical para demonstrar a compatibilidade da razão matemática e da natureza invisível. Hume foi o advogado que ansiou contestar as concepções racionalistas da filosofia, inclusive a própria filosofia, em seus esforços para fundar um saber empírico. Hegel foi o teólogo que tenta demonstrar que o movimento da razão ultrapassa as contradições de todos os sistemas de saber, inclusive o saber filosófico. Nietzsche foi o filólogo que se interessou pelos investimentos que presidem a produção do saber e do valor. Peirce foi o cientista que desejou submeter a ciência e a filosofia a investigações mais rigorosas. William James, médico, fez o mesmo e se dedicou a formas de pesquisa radicalmente empíricas, tomando a realidade como guia de humildade teórica. Jaspers, um psiquiatra, colocou em questão a filosofia enquanto esforço corajoso, porém cambaleante, para incorporar a totalidade do real. Frege, Husserl, Russell e Wittgenstein preocuparam-se com a completude do raciocínio lógico e os quadro se chocaram com a sua incompletude. Eles se voltaram, então, para a incompletude do conhecimento filosófico. Husserl e Wittgenstein, particularmente, levaram a filosofia para além dela mesma. A lista poderia se estender, mas o que eu quero mostrar é que essa abordagem não difere daquela de filósofos negros da época moderna. Wilhelm Amo, um médico e jurista akan do século XVIII, levanta a possibilidade de raciocinar para além da própria filosofia quando ele reflete sobre as questões em torno da dignidade humana e desemboca em uma crítica da antropologia e da psicologia cartesianas, fundadas sobre o dualismo corpo/espírito (WIREDU, 1996; GORDON, 2008a). Quobna Ottobah Cugoano, um Fanti que escrevia na Londres do século XVIII, não se preocupava em saber se ele era filósofo quando criticava as considerações racistas de Hume acerca dos Negros. Ele examina o problema da linguagem e do pensamento de Deus e de sua relação teodiceana com a escravidão (HENRY, 2004). Du Bois, oficialmente historiador e sociólogo, colocou em questão as condições de produção do saber social e as antropologias que levavam à degradação dos povos (DU BOIS, 1898, 1903, 2000). Ainda que desencorajado por William James de explorar esses domínios lançando mão da filosofia, Du Bois os 
trata em termos ironicamente filosóficos através de sua transcendência. Ele produziu uma nova filosofia com sua contribuição ao pensamento negro e desempenhou um papel central na filosofia Africana (GORDON, 2008a). Anténor Firmin é de mesma estatura. Advogado de formação, ele respondeu à antropologia filosófica racista do séc. XIX através de uma filosofia das ciências humanas extremamente avançada (FIRMIN, 2004). Apesar de seu doutorado em filosofia, Alain Locke interessou-se por questões relativas à cultura e ao valor de uma maneira que ultrapassava a filosofia e influenciava sobre os diversos movimentos intelectuais negros, que contribuíam, sem exceção, à filosofia Africana. Enfim, Fanon, psiquiatra de formação, oferece igualmente perspectivas que ultrapassam a filosofia.

De qualquer maneira, busquei sublinhar a questão da existência negra a partir do "exterior". Colocar-me no "interior" dela exige desenhar duas perspectivas que Du Bois (1903), entre outros, caracterizou como uma consciência dupla, aquela que tem 1) uma versão inicial e 2) uma versão crítica e potencializada (HENRY, 2005; GORDON, 2000). A primeira consiste em se ver (a si mesmo ou seu grupo) através dos olhos freqüentemente hostis daqueles que nos constituem como um termo subordinado. Para os Negros, isso significa ver a negritude a partir de uma perspectiva anti-Negros, ou seja, se sentir um problema, expressar um problema, ser um problema. A segunda, ao contrário, surge da distinção entre "ser um problema" e "ter problemas". Essa consciência alargada evidencia a problemática das forças sociais implicadas na construção de sua própria inferioridade. Desloca-se da aceitação ingênua de um sistema para o desenvolvimento de uma perspectiva crítica sobre suas pressuposições. Esse movimento exige que se identifique e ilumine as contradições sistêmicas. Cada contradição desvela um falso universal, o que provoca uma expansão rumo a uma compreensão mais profunda do mundo em torno de nós. Na verdade, o particular é alargado ao mesmo tempo em que se opera a particularização daquilo que, anteriormente, pretendia-se universal. O movimento é dialético, pois ele atualiza as contradições, mas não se trata de uma dialética fechada no sentido de que se interromperia antecipadamente, a priori, uma validade e uma interpretação dialética. Em termos mais prosaicos, a dupla consciência reconhece a roupa suja de uma sociedade moderna e oferece, dessa maneira, uma imagem mais precisa do pensamento moderno, a qual ela examina sem fazer apelo a sistemas de saber fechados: é uma reflexão que ultrapassa a teodicéia.

Nossa problematização da crítica do método efetuada por Fanon possui um caráter eminentemente fenomenológico. Não se pode esquecer que a fenomenologia convida a suspender nossa atitude natural ou nossos engajamentos ontológicos quando examinamos os fenômenos (HUSSERL, 1947; GORDON, 1995). Ora, entre esses fenômenos, pode-se igualmente incluir nossos modos de raciocínio, inclusive o raciocínio fenomenológico. Por conseqüência, é preciso colocar em questão não somente a lógica, mas 
também as reduções, colocações entre parênteses e suspensões fenomenológicas. Esse esforço radical implica não pressupor método algum, mas chegar a nossas conclusões livres do jugo ou da força colonizadora de certas formas de racionalidade. Fanon, como vimos, escolheu essa abordagem de modo a que seus esforços se tornassem fenomenológicos, mas é um gesto fenomenológico atenuado precisamente porque a própria fenomenologia, considerada como operação autocrítica legítima, torna-se suspeita. Assim, as reduções de Fanon são, tal como Nelson MaldonadoTorres (2007) pertinentemente as caracterizou, reduções decoloniais. O mesmo pode ser dito acerca da dupla consciência. É evidente o aspecto fenomenológico da dupla consciência, posto que a fenomenologia também trata daquilo de que nós somos conscientes,ou, ao menos, das significações constituídas por essa consciência. Porém, a dupla consciência acrescenta, sobretudo em sua forma potencializada, uma concepção das representações do eu enquanto produtos de universos de consciência em conflito. Em outras palavras, a dimensão da consciência dupla inicial difere da consciência dupla potencializada. Essa última oferece um mundo através do qual a realidade anterior, vivida de maneira ingênua, é compreendida como exígua e claustrofóbica e a submete à potência das relações intersubjetivas ou sociais, o que Fanon (1971, p. 10) chama de significação "sociogênica". Esses mundos sociais, que Du Bois e outros descrevem através da metáfora de lugares divididos por véus, trazem à luz a significação filosófica da cultura, para a qual dedicaremos nossa atenção de agora em diante.

\section{Cultura, símbolo, mundo}

Nossa discussão acerca da dupla consciência faz emergir um fato social bastante conhecido, embora freqüentemente desprezado no contexto das democracias liberais das Américas (do norte e do sul), da Austrália e da Europa: os Negros e os Brancos, em sua maioria, vivem em mundos diferentes. Isso não significa que não haja passagens, nem pessoas que se movem em diferentes dimensões de um modo regular ou por escolha de vida em termos pessoais, nem pessoas que não entram nas categorias Negros e Brancos. Entretanto, em geral, há coisas que são inacessíveis enquanto esses mundos buscam ser vividos como entidades completas. O argumento da dupla consciência acrescenta, contudo, algo que desestabiliza a aparente simetria dos Negros e dos Brancos. Enquanto o mundo negro deve conhecer ao mesmo tempo o mundo branco e o mundo negro (e outros mais), o mundo branco ignora largamente o mundo negro. Por consequiência, o mundo branco vive essencialmente segundo as leis de uma realidade diminuta. Essa assimetria coloca o poder no lado dos brancos, mas ela representa igualmente uma ruptura entre saber e poder, com exceção de onde o saber é instrumental (já que ele visa a perpetuar o sistema). Pode-se, portanto, dizer que o saber social pelo menos, e aquilo que se poderia 
chamar de "fatos" do mundo social, não são entravados pelos mecanismos de poder, mas lutam continuamente com ele: a liberação dos grupos colonizados inclui igualmente a liberação do saber.

Entretanto, os Negros e os Brancos não vivem vidas completamente apartadas, mas integram um continuum de realidade social a que se dá o nome de cultura. Utilizo essa palavra para expressar mais do que a maneira de viver de uma comunidade humana somente. É o mundo humano e esse mundo é governado por dimensões que ultrapassam o espaço e o tempo, a saber, entre outros, o simbólico e o dimensional.

Muito se fala acerca da cultura nas ciências humanas e na crítica social e política, mas se perde de vista com freqüência sua complexidade em proveito de pressuposições de representações populares em torno de maneiras e costumes, em que os grupos parecem "ter" uma cultura, do mesmo modo que se tem um estilo ou uma moda. Em filosofia, a situação é agravada pelo fato de que falar da cultura coloca os mesmos problemas que falar dos Negros. Dir-se-ia que a razão deixa o recinto quando a cultura entra com sua bagagem de mitos, de religiões, de poesia, de música e de todos esses elementos kinestéticos. A potente ligação da filosofia Africana com a filosofia da cultura não é acidental, porque ambas colocam em evidência elementos da filosofia moderna que suscitam ansiedade, às vezes até mesmo a total rejeição, entre os filósofos que se sentem obrigados a oferecer um conhecimento autônomo em relação à cultura. No entanto, gostaria de sublinhar há uma ambigüidade na ideia de um conhecimento autônomo em relação à cultura. De um lado, o relativista sustenta que somos determinados e limitados por uma cultura específica em oposição a outra. Por outro lado, há um conceito de cultura mais global e que transcende paradoxalmente as culturas: segundo essa concepção, ser limitado pela cultura não remete a uma cultura específica, mas à cultura enquanto condição transcendental do conhecimento filosófico (WIREDU, 1996; MOODY-ADAMS, 1997). Nesse caso, a ameaça ao anti-culturalista tornase grave.

A cultura é a realidade simbólica criada pelos seres humanos. Ela oferece significações graças às quais um mundo humano procura ser também um mundo habitável. As origens da cultura são, de um lado, uma questão de sobrevivência, e de outro, uma luta contra as forças da aflição, da ansiedade e do desespero. O aparecimento da linguagem simbólica, em oposição à simples comunicação, levou a espécie humana a um mundo de significações cuja capacidade está em perpétua expansão. Esse mundo envolve a memória, a antecipação com grande antecedência, bem como todo tipo de outros recursos mentais e sociais que fizeram a espécie humana passar do perigo de extinção (reduzida a um total de dois mil indivíduos, há 74 mil anos, contra 6 bilhões hoje) a uma humanidade em pleno crescimento, ainda que não necessariamente feliz (ANITEI, 2007; FINCH, 1991). Esse notável êxito suscitou, como Freud (2010) pôde observar, uma 
resposta incomum a uma das fontes da infelicidade humana: os outros. Freud atribui a infelicidade humana às forças contingentes e fortuitas da natureza, às limitações de nosso próprio corpo e à coexistência com outros seres humanos. Nenhum de nós é mais forte do que a natureza: um dia nossos corpos se enfraquecerão e morrerão; e os outros são freqüentemente indignos de confiança. Ao invés de uma realidade hostil, implacável, niilista, fora da realidade humana, ou seja, um universo que não tem nenhum motivo para cuidar de nós, o mundo humano da cultura a substitui e oferece não somente um mundo feito para nós, mas também recursos que nos permitem ultrapassar nossas fraquezas físicas e nossa condição mortal graças à presença contínua de nosso espírito, que desempenha o papel de memória social. Ele limita igualmente nossa liberdade e aquela de outrem e regula a conduta humana pautada pela força. Esses aspectos criador e regulador da cultura acompanham, segundo Freud, a construção de um deus protético.

A construção de deuses protéticos levanta um outro aspecto metafilosófico da filosofia da cultura. $\mathrm{Na}$ história da filosofia, o idealismo transcendental, representado essencialmente na tradição européia por Kant e Hegel, exerceu uma influência profunda sobre o pensamento moderno e pós-moderno, modificando seu ponto de vista: não mais perguntar o que é conhecido, mas o que pode ser conhecido em função do modo pelo qual esse conhecimento é possível. Essa mudança, para a qual Kant (2006) ofereceu o famoso título de segunda revolução copernicana, colocou as condições de possibilidade ainda mais na interioridade. Essa trajetória célebre, ilustrada por uma tradição que inclui Herder, Kant, Hegel e muitos outros, foi da experiência à história, à linguagem, aos signos, e desembocou no estruturalismo e na semiologia, até chegar na cultura como condição de possibilidade (CASSIRER, 1975; CAWS, 1988). Entretanto, a criação desse deus protético foi influenciada por esses elementos (experiência, linguagem, símbolos), de tal maneira que ele produz e governa a partir disso as condições de muitos desses elementos. O produto se tornou produtor, ou ao menos afeta o produtor.

Cassirer, como se sabe, é a figura que, no pensamento europeu do séc. XX, domina o estudo explícito da cultura enquanto empreendimento filosófico. Ele considerava a cultura como uma expressão da liberdade humana, um efeito de nossa capacidade de construir um mundo simbólico, viável em termos humanos. Em seu Ensaio sobre o homem, ele faz rapidamente observações cuja profundidade talvez lhe tenha passado despercebida (CORNELL \& PANFILIO, 2010), particularmente no momento em que ele argumenta que o simbólico não é um acréscimo à realidade, mas uma dimensão diferente da realidade:

O círculo funcional do homem não somente alargou-se, mas também sofreu uma mudança qualitativa. O homem descobriu, por assim dizer, um novo método de adaptação ao meio. Entre 
os sistemas receptor e de reação, presentes em qualquer espécie animal, encontramos no homem um terceiro elo, que podemos designar como sistema simbólico. Essa nova aquisição transforma o conjunto da vida humana. Comparado aos outros animais, o homem não vive apenas numa realidade mais vasta; vive, por assim dizer, numa nova dimensão da realidade (CASSIRER, 1975, p. 43).

Esse ponto ilumina a distinção anterior entre raiz cultural particular e raiz cultural como tal. Esta última não constitui uma coação para o saber. Ela é a própria emergência do saber enquanto alguma coisa que faz sentido. Saber é entrar num mundo; experimentar, pensar, comunicar, empreender e desenvolver a multiplicidade de meios simbólicos que conferem sentido à vida implica que se entre também nesse mundo.

\section{Considerações finais}

Volta-se, dessa maneira, ao triunvirato inicial da existência negra tal como a compreende a filosofia Africana. Nessa altura, é possível acrescentar idéias suplementares. A discussão em torno de universal/particular, em que as representações brancas hegemônicas são presumidas como universais e as negras como particulares, é um exemplo disso. Se procuramos compreender como mundos diferentes ocupam espaços partilhados, a questão das culturas se torna difícil, pois elas são freqüentemente vividas como universais e associadas a uma impressão falaciosa de totalidade. Que a cultura seja global para os seres humanos significa, por outro lado, que os aspectos intersubjetivos das reivindicações culturais possam ser valorizados em virtude de sua incompletude inicial. A incompletude da cultura é uma função da reflexão da humanidade sobre ela própria. Qualquer tentativa de maximizar a coerência lógica da realidade cultural se choca com o problema da inumanidade de uma tal concepção do mundo humano. As condições inaugurais da cultura estariam comprometidas devido a uma falha da razão: a mais coerente cultura seria irracional e, para a maioria dos homens, indesejável. A relação entre a antropologia filosófica, a liberdade e a reflexão metacrítica sobre a razão vem, portanto, em primeiro plano, na filosofia da cultura.

Gostaria de concluir com uma observação acerca da cultura e da liberdade, que formaram o pano de fundo desta discussão. Trata-se de uma relação sobre a qual Ernst Cassirer insistiu, como vimos, e da qual um elemento importante aparece no pensamento de Freud. A liberdade exige mais do que a ausência de forças vinculantes. A eliminação das correntes produz a liberdade, mas não necessariamente a licença. Não estar impedido não é a mesma coisa que ser livre. Para ser livre, devemos pertencer a um lugar, ter um lar. Essa concepção remonta aos tempos da antigüidade, em que as reflexões acerca do exílio realçaram esse ponto. Ser liberto de 
perseguições graças à proteção oferecida pela casa de um outro assegura a segurança, mas não a liberdade. Para ser livre, deve-se poder ficar sem reservas, legitimamente, e ter uma justificativa para ficar. Tal é a condição para estar em casa. Mas o lar, nesse sentido, não designa necessariamente um domicílio real. Pode ser uma residência simbólica e epistemológica. Pode-se, por exemplo, conseguir uma forma de liberdade encontrando sua residência intelectual, sua residência artística, esses elementos da vida que fazem com que nós nos sintamos em casa no mundo (GORDON, 2008b).

A melancolia, à qual fiz referência acima, está ligada a essa concepção. A filosofia Africana lida com as contradições dos povos negros e do povo Africana que supostamente não teriam legitimidade em um mundo onde eles são indígenas. Não há outro mundo onde o povo negro e Africana existiu, e talvez pudesse existir, a não ser o mundo moderno. A consequiência disso consiste em privá-los de sua casa no único mundo a que poderiam pertencer. Da mesma maneira que a filosofia da cultura define a liberdade humana através de uma concepção da cultura que a compreende como tentativa humana de estar em casa na existência, também a filosofia Africana persegue o projeto de fazer com que o povo e suas idéias estejam em casa no mundo enquanto uma demanda fundamental da liberdade. 


\section{Referências bibliográficas}

ANITEI, Stefan (2007). 74,000 Years Ago, the Human Species Was at the Brink of Extinction », Softpedia, 2007. Disponível em: news.softpedia.com/news/ 74-000-Years-Ago-Human-Species-Stood-at-theBrink-of-Extinction-66978.shtml .

BUCK-MORSS, Susan. Hegel, Haiti, and Universal History. Pittsburgh : University of Pittsburgh Press, 2009.

CASSIRER, Ernst. Essai sur l'homme, trad. Norbert Massa. Paris : Minuit, 1975.

CAWS, Peter. Structuralism: The Art of the Intelligible. Atlantic Highlands, NJ : Humanities International Press, 1988.

CHRISMAN, Laura. "Postcolonial Studies and Black Atlanticism », conferência dada no dia 28 de março de 2002, no Departamento de Estudos Africanos e Ingleses da Universidade do Kansas. Disponível em: http://www2test.ku.edu/ kasc/research/

publications/Publications_Transcriptions/chrisman.shtml.

CORNELL, Drucilla \& PANFILIO, Kenneth. Symbolic Forms for a New Humanity: Cultural and Racial Reconfigurations of Critical Theory. New York : Fordham University Press, 2010.

DU BOIS, W. E. B. The Study of Negro Problems. The Annals of the American Academy of Political and Social Science, XI : p. 1-23, 1898.

A. C. McClurg \& C ${ }^{\circ}, 1903$. The Souls of Black Folk: Essays and Sketches. Chicago : Sociology Hesitant. Boundary 227(3), 3744, 2000.

FANON, Frantz. Peau noire, masques blancs. Paris : Seuil, 1971.

FISCHER, Sibylle. Modernity Disavowed: Haiti and the Cultures of Slavery in the Age of Revolution. Durham, NC : Duke University Press, 2004.

FREUD, Sigmund. Deuil et mélancolie. Paris : Payot, 2011.

Malaise dans la civilisation. Paris : Payot, 2010.

FINCH, Charles S. III. Echoes of the Old Darkland: Themes from the African Eden. Decatur, GA : Khenti, 1991.

FIRMIN, Anténor. De l'égalité des races humaines. Paris : L'Harmattan, 2004.

GORDON, Lewis R. Fanon and the Crisis of European Man: An Essay on Philosophy and the Human Sciences. New York : Routledge, 1995.

\section{Existentia Africana: Understanding Africana}

Existential Thought. New York/Londres : Routledge, 2000. Disciplinary Decadence: Living Thought in Trying

Times. Boulder, CO : Paradigm Publishers, 2006. . An Introduction to Africana Philosophy. Cambridge :

Cambridge University Press, 2008a. 
. Not Always Enslaved, Yet Not Quite Free:

Philosophical Challenges from the Underside of the New World. Philosophia : Philosophical Quarterly of Israel 36(2), p. 151-166, 2008b.

GOULD, Stephen J. The Mismeasure of Man. New York : Norton, 1981.

HENRY, Paget. Caliban's Reason: Introducing Afro-Caribbean Philosophy. New York : Routledge, 2000.

Between Hume and Cugoano: Race, Ethnicity and

Philosophical Entrapment. The Journal of Speculative Philosophy, 18(2), p. 129-148, 2004.

. Africana Phenomenology: Its Philosophical Implications.

The C.L.R. James Journal, 11(1), p. 7-112, 2005.

HUSSERL, Edmund. Méditations cartésiennes, Paris : Vrin, 1947.

KANT, Immanuel. Critique de la raison pure, trad. A. Renaut. Paris : Garnier-Flammarion, 2006.

KIERKEGAARD, Søren. Crainte et tremblement. Paris : Rivages, 2000. La Répétition. Paris : Rivages, 2003.

MALDONADO-TORRES, Nelson. Against War: Views from the Underside of Modernity. Durham : Duke University Press, 2007.

MIGNOLO, Walter. Philosophy and the Colonial Difference. Philosophy Today, 43(4), p. 36-41, 1999.

MOODY-ADAMS, Michelle. Fieldwork in Familiar Places: Morality, Culture, \& Philosophy. Cambridge, MA : Harvard University Press, 1997.

TAYLOR, Paul. The Concept of Race. Cambridge : Polity, 2004.

WIREDU, Kwasi. Cultural Universals and Particulars: An African Perspective. Bloomington : Indiana University Press, 1996. 